\author{
Raimonds Rublovskis \\ Latvijos tarptautiniu santykiu institutas
}

\title{
Latvijos saugumo ir gynybos politika XXI amžiaus saugumo aplinkoje
}

\begin{abstract}
Šio straipsnio tikslas - išanalizuoti pagrindinius veiksnius, kurie formuoja ir iš esmès modeliuoja Latvijos Respublikos saugumo ir gynybos politiką. Būtų galima teigti, kad istorinès aplinkybès, geografine padètis, bendra institucinè istorija, buvusios Sovietų Sąjungos rèmuose, Rusijos veiksnys, palyginti nedidelè valstybės teritorija ir gyventojų skaičius, etninė gyventojų sudètis, nedidelis gyventojų tankis, riboti finansiniai ir žmogiškieji ištekliai, skirti Latvijos Respublikos gynybai yra pagrindiniai veiksniai, lemiantys valstybės saugumo ir gynybos politiką. Esminiai Latvijos saugumo ir gynybos politikos principai yra naryste pasauliniame kariniame NATO aljanse ir dvišale strateginė partnerystė su Jungtinėmis Amerikos Valstijomis. Visgi, trijų Baltijos valstybių bendradarbiavimas saugumo ir gynybos srityje, o taip pat sustiprejęs bendradarbiavimas su Baltijos ir Šiaurès šalimis traktuojamas kaip svarbus papildomas veiksnys, didinantis Latvijos Respublikos saugumą. Latvija išplètojo tvarią teisinę ir institucinę struktūrą, skirtą valstybès saugumui ir gynybai stiprinti, tačiau saugumo iššǔkiai ir svarbūs pokyčiai globalioje XXI amžiaus saugumo aplinkoje ir toliau mes iššūkius Latvijos Respublikos gebejjimui išlaikyti esamą teisinę struktūrą ir, dar svarbiau, esamą institucinę Latvijos saugumo ir gynybos struktūrą. Svarbūs vidiniai ir išoriniai iššūkiai darys poveikị esminiams Latvijos saugumo ir gynybos politikos aspektams, tokiems kaip Amerikos strateginis poslinkis Ramiojo vandenyno šalių link ir politinès valios stoka padidinti gynybos išlaidas europinèje NATO dalyje. Turètų būti aišku, kad pati Latvijos Respublikos nepriklausomybė, saugumas ir gynyba priklauso nuo NATO sugebejjimo išlikti veiksminga organizacija, laiku ir efektyviai priimančia sprendimus, ir nuo Jungtinių Amerikos Valstijų sugebejimo išlikti veiksmingoms karine prasme ir laikytis ịsipareigojimų dèl Europos saugumo ir gynybos.
\end{abstract}

\section{Ivadas}

Sudètinga XXI amžiaus pradžios saugumo ir gynybos aplinka sukūrè naujus pavojus ir iššūkius. Mažosios valstybès tampa vis labiau pažeidžiamos dèl grèsmių ir iššūkių, susijusių su saugumu, o Latvija, būdama mažąa valstybè ir turèdama gana ribotus išteklius ir karinius pajėgumus, yra ypač pažeidžiama. Istoriniai, geografiniai, instituciniai ir kiti aspektai turi dideli poveiki Latvijos saugumo ir gynybos suvokimui ir, atitinkamai, Latvijos saugumo

\footnotetext{
* Raimonds Rublovskis - Latvijos tarptautinių santykių instituto mokslinis bendradarbis. Adresas: Pils street 21, LV-1050 Riga, Latvia, el. p. raimonds.rublovskis@liia.lv
} 
ir gynybos politikai XX amžiaus pabaigoje ir XXI amžiaus pradžioje. Būtina suvokti, kad Latvijos Respublikos saugumas, gynyba ir pati nepriklausomybe priklauso nuo svarbių išorinių veiksnių ir nuo reikšmingų vidinių aplinkybių. Latvijos narystė NATO ir strateginė partnerystè su Jungtinėmis Amerikos Valstijomis visuomet buvo svarbiausi esminiai šalies saugumo ir gynybos politikos elementai. Tačiau negalima neittraukti $\mathfrak{t}$ Latvijos saugumo ir gynybos darbotvarkę svarbaus Rusijos veiksnio. Be abejo, Latvija visada buvo suinteresuota palaikyti pragmatiškus ir pozityvius santykius su Rusija.

Šio straipsnio tikslas - išanalizuoti pagrindinius veiksnius, kurie formuoja ir iš esmès modeliuoja Latvijos Respublikos saugumo ir gynybos politiką, teisinę ir institucinę saugumo ir gynybos sektoriaus struktūrą, bendrais bruožais nusakyti Latvijos saugumo ir gynybos politikos iššukius ateityje.

\section{Pagrindiniai Latvijos saugumo ir gynybos politikos aspektai (veiksniai)}

Latvijos saugumo ir gynybos politikos prioritetai buvo formuojami remiantis keletu pagrindinių veiksnių - istorinès aplinkybès, geografinè padètis, Rusijos veiksnys ir etninè Latvijos gyventojų sudètis, palyginti nedidelè šalies teritorija ir institucinis ir karinis Jungtinių Amerikos Valstijų ir NATO Aljanso gebejjimas sẻkmingai vykdyti savo ịsipareigojimus Latvijai ir kitoms Baltijos valstybèms. Visi šie aspektai turi didelị ir ilgalaikị poveikị pačiam Latvijos plačiosios visuomenès, taip pat ir politinès vadovybés supratimui apie saugumą ir gynybą.

\subsection{Istorinès aplinkybès}

Istorinės aplinkybės yra vienas iš svarbiausių veiksnių, kuris daro dideli poveikị buvusiai ir esamai Latvijos saugumo ir gynybos politikai. Jos didele dalimi formuoja Latvijos grèsmès suvokimą ir jos saugumo ir gynybos reikalus. Turint omenyje pati faktą, kad nuo XVI amžiaus Latvijos teritorija buvo karinių konfliktų tarp politine ir karine prasme galingų kaimynų vieta, galima būtų teigti, kad istorinès aplinkybès, darančios ịtaką dabartinei Latvijos saugumo ir gynybos politikai siekia tolimą istoriją, net XVI-XVIII amžius, kai dabartine Latvijos Respublikos teritorija buvo dalis Lenkijos-Lietuvos valstybès, Švedijos ir, galiausiai Rusijos imperijos ${ }^{1}$.

\footnotetext{
${ }^{1}$ Blank S.J., European Security and NATO Enlargement, Carlisle, PA: U.S. Army War College, 1998, p. 122.
} 
XX amžius turejo ypač dideli poveikị Latvijos dabartinès gynybos politikos reikalų plètrai. Pirmojo pasaulinio karo padariniai sudare palankias sąlygas pirmą kartą istorijoje ịkurti nepriklausomą Latvijos valstybę. Vèlesnis nepriklausomybès praradimas per Antrajj pasaulinị karą 1940 metais ir daugiau negu 50 metų patirties buvusioje Sovietų Sąungoje, toliau formavo grèsmès suvokimo ir pageidaujamos saugumo politikos supratimą ${ }^{2}$. Latvija ir kitos Baltijos valstybės atgavo nepriklausomybę 1991 m., pasibaigus Šaltajam karui. Iširus Varšuvos paktui, Vidurio ir Rytų Europoje, taip pat ir Latvijos Respublikoje prasidejo dideli saugumo ir gynybos politikos ir susitarimų pokyčiai. Be abejo, nepriklausomybę atkūrusios Baltijos šalys suprato, kad vienintelę svarbią jų nepriklausomybei karinę grèsmę kelia kaimynas iš Rytų ir kad ta grèsmė būtų subalansuota ir atremiama dèl saugumo ir gynybos susitarimų pasaulinès saugumo organizacijos remuose, kur yra bent vienas ar keli politine, ekonomine ir karine prasme galingi veikejai, turintys globalaus saugumo interesų ir globalias karines ribas.

Be abejonès, šiuo požiūriu Latvija visada laikèsi nuomonès, kad Jungtinès Valstijos ir NATO yra pagrindiniai šalies gynybos ir saugumo garantai, ypač turint omenyje politinius ir teisinius NATO įsipareigojimus įsikišti, jei bet kuris Aljanso narys būtų užpultas, taip pat atsižvelgiant ị didelius ịprastinès ginkluotès ir branduolinius pajėgumus ir įsipareigojimą panaudoti tuos pajègumus pagal pagrindines NATO nuostatas. Jau vien tai, kad Jungtinès Amerikos Valstijos niekada nepripažino Latvijos ir kitų Baltijos valstybių inkorporavimo ị Sovietų Sąjungą nuo 1940 m. iki 1991 m., suvaidino lemiamą vaidmenị Baltijos valstybėse. ${ }^{3}$ Nuo 2004 m. Latvija, kaip ir kitos Baltijos valstybès, yra visateisè NATO Aljanso nare ir būtų galima tvirtinti, kad Latvijai dabar būdingas kaip niekad aukštas saugumo ir gynybos susitarimų lygis. Būtų galima padaryti išvadą, kad istorinė Latvijos patirtis, ypač XX amžiuje, vis dar išlaiko karinès grèsmès iš Rytų kaimynystès sąvoką ir ši sąvoka toliau reikšmingai formuoja ir veikia Latvijos Respublikos saugumo ir gynybos politiką.

\subsection{Geografija ir dydis}

Kitas svarbus klausimas, kuris veikia saugumo ir gynybos problemas Latvijoje, yra geografija ir palyginti nedidele Latvijos teritorija. Baltijos valstybès yra patyrusios, kad geopolitika ir geostrategija yra linkusios būti cikliškai

\footnotetext{
${ }^{2}$ Bilinsky Y. Endgame in the NATO's Enlargement, Westport, CT: Praeger, 1998, p. 9.

${ }^{3}$ Meyer K. R.," US Support for Baltic Membership in NATO: What Ends, What Risks?", Parameters, U.S. Army War College Quarterly, Volume XXX (4), 2000, p. 75.
} 
grèsmingos, kai nacionalinè teritorija yra ties vartais, vedančiais $\mathfrak{i}$ ir iš žemyninès Europos. ${ }^{4}$ Geografinè padetis yra vis dar svarbi ir ji suvaidino lemiamą vaidmenị ịvertinant karinį Latvijos ir kitų Baltijos valstybių apginamumą prieš istojant i NATO. ${ }^{5}$ Be abejo, geografiné padetis ir pats supratimas apie Latvijos apginamumo ịprastinèmis karinèmis priemonemis lygị vis dar vaidina svarbų vaidmeni Latvijos saugumo ir gynybos reikaluose. Latvijos „mažumo“ problema taip pat lemia Latvijos saugumo ir gynybos mąstyseną. Nèra aiškaus apibūdinimo, ką reiškia būti mažąja valstybe. Kokybinis apibūdinimas apima mažųjų valstybių fizines ir geografines charakteristikas, izoliuotumo laipsnį ir pažeidžiamumą, o kokybinis sausumos plotą, gyventojų skaičių, bendrąji nacionalinị produktą, bendrąji vidaus produktą ir pajamas, tenkančias vienam gyventojui. Galima būtų teigti, kad mažoji valstybė taip pat galètų reikšti, kad tam tikra valstybė yra mažesnè negu dauguma jos kaimynių arba kad ji yra mažesnè negu regiono vidurkis, o tiesioginis to rezultatas nacionalinès galios ir savo teisių gynimo prasme būtų pranašumo neturẻjimo jausmas. Akivaizdu, kad mažosios valstybès turètų labai ribotas politinès, ekonominès ir karinès galios priemones, o jų politinis ir karinis vadovavimas taip pat būtų mažesnio masto ir menkiau kvalifikuotas. Gal būtų galima daryti prielaidą, kad pagrindinis veiksnys, lemiantis mažosios valstybès apibūdinimą, yra ne vien teritorijos dydis, gyventojų skaičius, ekonomika ir kariniai pajègumai. Greičiau jau būtų galima teigti, kad savo saugumo ir gynybos reikalų požiūriu, didelè mažosios valstybès priklausomybe nuo politine prasme stipraus, o karine - pajègaus pasaulinio masto veikejjo ir (ar) saugumo ir gynybos organizacijos, kurioje toks veikejjas vaidina svarbų vaidmenį. Pagrindinis argumentas, siekiant nustatyti ar tam tikra valstybe yra ar nèra mažoji, yra imti nagrinèti jos svarbiausius saugumo ir gynybos klausimus. Dydis ir karinis ginkluotųjų pajėgų pajėgumas, visas valstybės saugumo sektorius, gynybos biudžetas ir realiụjų piniginių investicijų ir BVP procento prasme apibūdintų, ar saugumo ir gynybos perspektyvos požiūriu tam tikra valstybè galètų būti laikoma mažąja ar ne. Reikia atsižvelgti i patị faktą, kad Latvijos Respublikos „mažumas“ suponuoja tokią situaciją, dèl kurios šalis negali ir negalès daug investuoti finansinių išteklių ì technologinę ginkluotųjų pajègų plètrą. Tai reiškia, kad Latvija nebus pajègi pasiekti aukštesnio gynybos transformacijos ir modernizacijos lygio, todèl, palyginti su globaliomis ar regioninèmis valstybèmis, pastebimai atsiliks nuo dabartinių ginkluotųjų pajègų technologinès modernizacijos tendencijų.

Išoriniai saugumo aspektai vaidina pagrindinị vaidmenị mažosios vals-

\footnotetext{
${ }^{4}$ Grey C. S., Another Bloody Century, London: Weidenfeld and Nickolson, 2005, p. 76.

${ }^{5}$ Brzezinski Z., US Policy toward Northeastern Europe, New York, NY: Scribner, 1999, p. 24.
} 
tybės gynybos reikaluose. Be abejo, būtina pabrèžti išorinius veiksnius, susijusius su mažos valstybės saugumo mentalitetu. ${ }^{6}$ Latvija, turèdama 64589 kvadratinių kilometrų plotą ir apie 2 milijonus gyventojų, ịskaitant didesnes etnines mažumas, yra viena iš rečiausiai apgyvendintų ir turinčių mažiausią gyventojų skaičiu Europos šalių. Galima daryti išvadą, kad, Latvija galètų būti laikoma mažąja valstybe, kuri savo saugumo planų požiūriu yra visiškai priklausoma nuo galingų išorinių veikejų ir išorinių îvykių globalioje ir regioninèje saugumo aplinkoje.

\subsection{Rusijos veiksnys}

Rusijos veiksnys ir rusiškai kalbančios Latvijos mažumos klausimas yra dar vienas svarbus veiksnys, kuris daro didelę ịtaką platesniems Latvijos saugumo ir gynybos reikalams. Rusija pateikia nepatogią dilemą Latvijos ir Baltijos politikos strategams. ${ }^{7}$ Santykiai tarp Rusijos ir Jungtinių Amerikos Valstijų, Rusijos ir NATO taip pat turi dideli poveiki dvišaliams Latvijos ir Rusijos santykiams. Svarbiausi klausimai kalbant apie dvišalius ir daugiašalius santykius apima pačios Rusijos saugumą ir gynybos problemas, išdèstytas Rusijos 2009 m. Nacionalinio saugumo koncepcijoje ir Rusijos 2010 m. Karinëje doktrinoje. ${ }^{8}$ Iki $1991 \mathrm{~m}$. trys Baltijos valstybès buvo Sovietų Sąungos dalis; taip pat, Latvija ir Estija turi dideles rusiškai kalbančias mažumas, o ši aplinkybė daro didžiuli poveikị Latvijos saugumo ir gynybos reikalams ir dvišaliams jos santykiams su Rusija. ${ }^{9}$ Suprantama, rusiškai kalbančios mažumos klausimas visada buvo svarbus, net prieš Latvijai ịstojant ị NATO, kadangi kai kuriems veikẻjams Vakaruose buvo sunku įsivaizduoti NATO narę, turinčią didelę rusų mažumą ${ }^{10}$ Deja, Latvija ir kitos Baltijos valstybès per paskutiniuosius dvidešimt metų susikūrẻ bejẻgių rusofobų ịvaizdị ir NATO ir ES viduje tokiu mastu, kad buvo imtos vadinti „vieno klausimo“ tautomis, kurioms daugiau niekas nerūpi. ${ }^{11}$

Susirūpinimas dèl saugumo ir gynybos, išreikštas Rusijos dar prieš vè-

\footnotetext{
${ }^{6}$ Vayrynen R., Small States: Persisting Despite Doubts. The National Security of Small States in a Changing World, London: Frank Cass, 1997, p. 98.

${ }^{7}$ Paulauskas K.., "The Baltic Quest to the West: From Total Defence to 'Smart Defence' (and Back?) in Lawrence T.\& Jermalavičius T., eds., Apprenticeship, Partnership, Membership: Twenty Years of Defence Development in the Baltic States, Tallinn: International Centre for Defence Studies, 2013, p. 64.

${ }^{8}$ Kaljurand R., Neretnieks K., Ljung B., Tupay J., Developments in the Security Environment of the Baltic Sea Region up to 2020, Tallinn: International Centre for Defence Studies, 2012, p. 20.

${ }^{9}$ Knudsen O.F., Stability and Security in the Baltic Sea Region, Trowbridge: The Cromwell Press, 1999, p.101.

${ }^{10}$ Asmus R.D., Nurick R.C., NATO Enlargement and the Baltic States, Santa Monica, CA: RAND, 1996, p. 124.

${ }^{11}$ Paulauskas K., (7 išnaša). p.64.
} 
liau prasidejjusias NATO plètros ị Vidurio ir Rytų Europą bangas XX amžiaus pabaigoje ir XXI amžiaus pradžioje, buvo labai panašus i tą, kuris pateiktas dabartineje Rusijos Nacionalinio saugumo strategijoje ir dabartineje Rusijos Karineje doktrinoje. XX amžiaus pabaigoje, Rusijos diskursas apemė keletą esminių pareiškimų, perteikiančių tokị požiūrị: NATO yra agresyvus karinis blokas, kuris užpuola suverenias šalis ${ }^{12}$, Baltijos valstybių narystė NATO yra tiesioginè grèsmé Rusijos nacionaliniam saugumui ${ }^{13}$, Rusijos istorinè patirtis mena daug invazijų iš Vakarų, ${ }^{14}$ NATO gali panaudoti Baltijos valstybių teritoriją siekdama užpulti Rusiją be ịspejimo. ${ }^{15}$

Vèliau dèl NATO plètros ị Vidurio Europą ir Baltijos regioną Rusijos strategijoje numatyta, kad NATO neturi turèti bendros sienos su Rusija Baltijos regione, NATO susilaikytų nuo priešakinio savo karinès infrastruktūros dislokavimo Vidurio ir Rytų Europoje strategijos, o Baltijos valstybès išlaikytų statusą, panašų i Švedijos ir Suomijos. Tai neịvyko dèl $2004 \mathrm{~m}$. NATO plètros. Dabartinè Rusijos Karinè doktrina buvo parvirtinta $2010 \mathrm{~m}$. vasario mèn. Ji paremta Rusijos Nacionalinio saugumo strategija, patvirtinta 2009 m. gegužès mèn. ${ }^{16}$ Abu dokumentai buvo patvirtinti po $2008 \mathrm{~m}$. rugpjūčio mèn. ịvykusio karinio Rusijos ir Gruzijos konflikto, kuris sukèlè dideli susirūpinimą saugumu Latvijoje ir kitose Baltijos valstybèse. ${ }^{17}$ Pagal ši dokumentą, svarbiausia Rusijos saugumo problema yra kova už Rusijos strateginę vietą pasaulyje, nes šiai pozicijai mete iššǔkị „kai kurios šalys ir (ar) grupe šalių“. Pagal šią Karinę doktriną, didžiausios karinès grèsmès Rusijai yra: regioniniai konfliktai arti Rusijos sienų ir didejjantis NATO gebejimas ir pajegumas sèkmingai spręsti globaliu mastu iškylančias saugumo ir gynybos problemas, tai gali pakenkti Rusijai vaidinti svarbų globalų vaidmenị netolimoje ateityje. Labai svarbus klausimas, kurị Rusija gali traktuoti kaip tiesioginę karinę grèsmę, yra tolesnè NATO plètra, taip pat tolesnis NATO karinès infrastruktūros vystymas ir

\footnotetext{
${ }^{12}$ Simon J., NATO Enlargement. Opinions and Options, Washington DC: National Defense University, 1995 , p. 124.

${ }^{13}$ Arbatov A., Russia and the West. The $21^{\text {st }}$ Century Security Environment, New York, NY: Armonk, 1999, p. 47.

${ }^{14}$ Trampenau T. R., NATO Expansion and the Baltic States, Monterey, National Defense University, 1996, p. 88 .

${ }^{15}$ Arbatov A., (13 išnaša). p.64.

${ }^{16}$ Leijonhielm J., "Russian Foreign, Defence and Security Policy "in Hugemark B., ed., Friends in Need. Towards a Swedish Strategy of Solidarity with her Neighbors, Stockholm: Royal Swedish Academy of War Sciences, 2012, p. 96.

${ }^{17}$ Mannik E." 'The Evolution of Baltic Security and Defense Strategies" in Lawrence T.\& Jermalavičius T., eds., Apprenticeship, Partnership, Membership: Twenty Years of Defence Development in the Baltic States, Tallinn: International Centre for Defence Studies, 2013, p. 13.
} 
jos dislokavimas arti Rusijos sienų. Dalis Rusijos karinio atsako būtų tolesné karinių pajėgumų ir infrastruktūros plètra Kaliningrado srityje, taip pat didelio masto karinių pratybų Baltijos regione organizavimas. Atrodè, kad Rusija karinemis pratybomis „Zapad 2009“ ir Ladoga-2009“ atvirai grasino Lenkijai ir Baltijos valstybėms. ${ }^{18}$ Rusijos karinès pratybos „Zapad 2013“ padidino susirūpinimą saugumu Latvijos saugumo ir gynybos institucijose, tačiau jos neturètų būti suprantamos kaip tiesioginè saugumo grèsmė Latvijai. „Zapad 2013“ buvo planuotos kovinès karinès pratybos, kurias $2013 \mathrm{~m}$. rugsejo-spalio men. Baltijos regione organizavo Rusijos Federacija ir Baltarusijos Respublika. Latvijos Respublikos gynybos ministerijos požiūris ị pratybas „Zapad 2013“ ir jos atlikta daugelio ịvykių tarp „Zapad 2009“ ir „Zapad 2013“ pratybų analizė leido Latvijos Respulikos gynybos ministerijai pareikšti, kad šios pratybos demonstravo agresyvią poziciją prieš NATO Baltijos regione ir ypač prieš Latviją ir kitas Baltijos valstybes. Buvo siekiama karinio žaidimo forma atlikti puolimą visu frontu prieš Baltijos valstybes. Latvijos Respublikos gynybos ministerija traktavo šias karines pratybas ir ankstesnius ivvykius regione kaip Rusijos Federacijos bandymą padidinti savo karinį buvimą sausumos, jūros ir oro srityse Baltijos regione. Kita vertus, oficialiame Rusijos paaiškinime buvo teigiama, kad pratybos, kuriose dalyvavo 12000 Rusijos ir Baltarusijos karių buvo vien gynybinio pobūdžio ir neturejjo planų vykdyti puolamąsias karines operacijas prieš bet kurią NATO narę Baltijos regione.

NATO, Jungtinès Amerikos Valstijos ir Latvija, kaip visateisè Aljanso narè, turi atsižvelgti $\mathfrak{i}$ Rusijos saugumo ir karinius reikalus, kadangi beveik visi karinių grèsmių Rusijai šaltiniai, išdèstyti Rusijos karinèje 2010 m. doktrinoje, Rusijos yra traktuojami, kaip iššǔkiai saugumui, kylantys iš NATO ir Jungtinių Amerikos Valstijų, o ị Latvijos ir kitų Baltijos valstybių teritoriją Rusija gali žiūrèti kaip ị tiesioginị karinès grèsmés šaltinị. Todèl atrodo, kad ị Rusijos reikalus dèl saugumo ir gynybos Baltijos regione turètų būti žiūrima labai rimtai, nes Rusija turi savo pačios legitimių saugumo ir gynybos sumetimų. Galbūt Rusijos atsakas yra jos karinio biudžeto spartus didinimas nuo $2000 \mathrm{~m}$. nominaliais $20 \%-25 \%$ kasmet. ${ }^{19}$ Ambicingoms Rusijos karinems reformoms planuojama išleisti daugiau kaip 600 milijardų JAV dolerių, siekiant modernizuoti ginkluotąsias pajeggas per artimiausius 10 metų. ${ }^{20}$ Galima daryti išvadą, kad Rusijos veiksnys ateityje turès didelę ịtaką Latvijos saugumo ir gynybos reikalams.

\footnotetext{
${ }^{18}$ Somerville A., Kearns I., Chalmers M., Poland, NATO and non-Strategic Nuclear Weapons in Europe, London: Royal United Services Institute for Defense and Security Studies, 2012, p.3.

${ }^{19}$ Leijonhielm J., (16 išnaša). p.91.

${ }^{20}$ Kaljurand R., Neretnieks K., Ljung B., Tupay J., (8 išnaša). P.14.
} 


\subsection{Narystė NATO ir strateginè partnerystė su Jungtinèmis Amerikos Valstijomis}

Narystė NATO ir strateginė partnerystė su Jungtinėmis Amerikos Valstijomis yra pagrindiniai Latvijos saugumo ir gynybos suvokimo aspektai. ${ }^{21}$ Tačiau reikettų labai aiškiai apibrěžti, kad saugumas, gynyba ir pati Latvijos nepriklausomybè didele dalimi priklauso nuo NATO Aljanso gebejjimo susekti, atgrasinti, atremti ir, jei būtina, ịveikti būsimus saugumo iššūkius ir grèsmes. Tai reiškia, kad Latvija yra iš esmès suinteresuota palaikyti ir plètoti santykius su NATO ir Jungtinemis Amerikos Valstijomis kaip su pagrindiniu Latvijos Respublikos saugumo ir gynybos garantu, nes Latvijos požiūriu Jungtinès Amerikos Valstijos yra vienintelis iš tikrųjų svarbus veikejas. ${ }^{22}$ Latvija mato NATO ir Jungtines Amerikos Valstijas kaip esminị šalies saugumo, gynybos ir paties egzistavimo sergètoją. Jungtinès Amerikos Valstijos labai aiškiai išdèstė savo globalius strateginius planus $2010 \mathrm{~m}$. Nacionalinio saugumo strategijoje, $2011 \mathrm{~m}$. Nacionalineje karinejje strategijoje ir $2012 \mathrm{~m}$. Strateginèse gynybos gairèse, kurios rodo JAV ịsipareigojimą atnaujinti savo, kaip pasaulinio lyderio, vaidmeni. ${ }^{23}$ Galima konstatuoti, kad NATO institucinis efektyvumas ir karinis pajegumas yra svarbiausias dalykas, susijęs su Latvijos saugumo ir gynybos planais. Tačiau ir čia kyla problemų. Be išlygų būtina, kad Jungtinès Amerikos Valstijos išliktų politine ir karine prasme galingu, turinčiu globalių interesų ir globalių karinių siekių veikeju, kuris laikosi NATO ịsipareigojimų ir, esant reikalui, dalyvauja Baltijos regiono gynyboje. Dabartinès tendencijos rodo, kad Jungtinèms Amerikos Valstijoms kyla daug skubesnių ir svarbesnių iššūkių negu Europos saugumo problemos. Jungtinès Amerikos Valstijos jau reagavo ị kylančius saugumo iššūkius Tolimuosiuose Rytuose su savo Ramiojo vandenyno ašies strategija ${ }^{24}$. Kokios būtų amerikiečių Ramiojo vandenyno regiono strategijos pasekmès Europos saugumui, transatlantiniams ryšiams ir Latvijos saugumui ir gynybai?

Akivaizdu, kad Jungtinès Amerikos Valstijos sumažins savo įsipareigojimus Europai, kad galètų reaguoti ị iškylančius globalius iššǔkius. Tai taip pat reiškia, kad amerikiečiai turès paremti savo Ramųji vandenyną posūkio i strategiją dideliais kariniais pajègumais, kuriuos būtina dislokuoti daug arčiau

\footnotetext{
${ }^{21}$ The State Defence Concept, Riga: Ministry of Defence Republic of Latvia, 2012, p. 4.

${ }^{22}$ Clemmesen M. H.," On Baltic Views of the Swedish Declaration of Solidarity” in Hugemark B., ed., Friends in Need. Towards a Swedish Strategy of Solidarity with her Neighbors, Stockholm: Royal Swedish Academy of War Sciences, 2012, p. 143.

${ }^{23}$ Kaljurand R., Neretnieks K., Ljung B., Tupay J., (8 išnaša). P. 27.

${ }^{24}$ Ibidem, p. 10.
} 
Ramiojo vandenyno regiono. Tai reiškia, kad jų sausumos, laivyno, oro pajègų, jūrų pėstininkų ir specialiųjų operacijų pajęgų globalių pajegu projekciniai pajègumai bus dislokuoti daug arčiau tų rajonų, kuriuose iškyla grèsmių saugumui. Signalas Europai ir Baltijos valstybėms yra gana aiškus - europiečiai turi pripažinti, kad po kelerių metų amerikiečiai nebus didžiausi Europos ir Baltijos valstybiu gynejjai ir kad Europos šalys - Europos Sajjungos narès ir Europos NATO narès - turi rasti politinès valios ir reikiamų ištekliu prisiimti daug daugiau atsakomybės už Europos gynybą. ${ }^{25}$ Suprantama, kad anksčiau paminèti ịvykiai turès ịtakos NATO sugebejimui išlikti instituciškai aktyvia ir veiksminga organizacija, greitai ir efektyviai atliekančia sprendimų prièmimo procedūras.

Galima būtų daryti išvadą, kad dabar kyla problemų dèl pagrindinių Latvijos saugumo ir gynybos politikos ramsčių efektyvumo. Čia reiktų paminèti tolesnị Jungtinių Amerikos Valstijų dalyvavimą Europos gynybos reikaluose ir NATO veiksmingumą, atsižvelgiant ị karinių išlaidų disbalansą tarp Jungtinių Amerikos Valstijų ir Europos valstybių - NATO narių.

Istorinè Latvijos patirtis, jos geografinè padètis ir tai, kad šalis yra palyginti nedidelé, Rusijos veiksnys, strateginè partneryste su Jungtinèmis Amerikos Valstijomis, narystė NATO, etniné Latvijos sudètis - tai pagrindiniai veiksniai, formuojantys Latvijos saugumo ir gynybos politiką. Šie veiksniai daro įtaką svarbiausiems Latvijos saugumo ir gynybos politikos ramsčiams. Pagrindiniai Latvijos saugumo ir gynybos politikos ramsčiai yra šie: galimos karinès grèsmès Latvijos Respublikai mažinimas ${ }^{26}$, kolektyvinio saugumo ir kolektyvinès gynybos stiprinimas ${ }^{27}$, pasitikejjimas NATO ir jo sugebejimu vykdyti 5-ojo straipsnio ịsipareigojimus ${ }^{28}$, strateginè partnerystė su Jungtinèmis Amerikos Valstijomis ${ }^{29}$, Šiaurès ir Baltijos valstybių bendradarbiavimas saugumo ir gynybos srityje ${ }^{30}$, savo šalies gynybos karinių pajègumų plètojimas, tarptautinių saugumo įsipareigojimų vykdymas dalyvaujant tarptautinėse karinèse operacijose. ${ }^{31}$

\footnotetext{
${ }^{25}$ Kaljurand R., Neretnieks K., Ljung B., Tupay J., (8 išnaša). p.17.

${ }^{26}$ The State Defense Concept, (21 išnaša). p.5.

${ }^{27}$ Ibidem, p. 6.

${ }^{28}$ Ibidem, p. 4.

${ }^{29}$ Ibidem, p.5.

${ }^{30}$ Ibidem, p.5.

${ }^{31}$ Ibidem, p.6.
} 


\section{Latvijos Respublikos saugumo ir gynybos teisinè ir institucinè struktūra XXI amžiaus saugumo kontekste}

Nuo 1991 metų Latvijoje kuriami teisiniai ir instituciniai valstybès saugumo ir gynybos srities pagrindai. Latvijos įstojimas į NATO buvo esminé paskata keisti Latvijos nacionalinę saugumo ir gynybos politiką. Latvijos Respublikos Konstitucija yra pagrindinis visa apimantis dokumentas, susijęs ir su valstybès gynyba, o visos kitos teisinès nuostatos yra sudarytos remiantis Latvijos Respublikos Konstitucija. Kuriant valstybės saugumo ir gynybos srities teisinę struktūrą, buvo remiamasi keletu pagrindinių dalykų: nacionaliniu saugumu ir gynyba (Valstybès saugumo ịstatymas, Pilietinès gynybos ịstatymas, Valstybės saugumo koncepcija, Valstybės gynybos koncepcija), teisiniu pagrindu Latvijos Respublikos ginkluotujų pajègų (LRGP) veiklai (Valstybės ginkluotụjų pajègų įstatymas, Valstybės savanoriškų pajègų ịstatymas, İstatymas dèl Nacionalinių ginkluotųjų pajègų dalyvavimo tarptautinėse karinėse operacijose, İstatymas dèl užsienio karinių pajègų statuso Latvijoje), karo prievole (Karo prievolès ịstatymas). Šie dokumentai yra teisinis Latvijos saugumo ir gynybos struktūros pagrindas. Taigi, pagrindiné institucija, atsakinga už valstybės gynybos politiką, yra Latvijos Respublikos gynybos ministerija. Latvijos Respublikos ginkluotosios pajègos (LRGP) yra pagrindinè institucija, atsakinga už valstybės gynybą, sausumos, jūros sienų ir oro erdvés neliečiamybę, teritorinį Latvijos vientisumą. ${ }^{32}$

Pagal Latvijos Respublikos Konstituciją, Latvijos Respublikos prezidentas, parlamentas (Saeima) ir vyriausybe turi didžiausius igaliojimus ir atsakomybę valstybès saugumo ir gynybos srityje. Tačiau yra keletas spręstinų klausimų, susijusių su Latvijos Respublikos Konstitucijos efektyvumu ir veiksmingumu, kurie iškyla analizuojant sudètingą XXI amžiaus saugumo aplinką tose srityse, kuriose veikia šis visuotinis teisinis dokumentas. Pagrindinius ịsipareigojimus ir uždavinius valstybės saugumo ir gynybos srityje turi prezidentas. Jis yra Latvijos Respublikos ginkluotụjų pajègų vyriausiasis vadas, karo metu jis skiria vyriausiajj Latvijos Respublikos kariuomenès vadą ir, remdamasis Latvijos Respublikos parlamento nutarimu, skelbia karą. Jis turi igaliojimus ir atsakomybę imtis bet kokių veiksmų, būtinų karinei valstybės gynybai. Parlamentas turi galią priimti sprendimus dèl karo ir nustatyti, kokio dydžio ginkluotujjų pajęgų reikia Latvijai taikos metu. Kai kuriais atvejais vyriausybė turi iggaliojimus paskelbti nepaprastąą padėti. Konstitucija kai kuriais aspek-

\footnotetext{
${ }^{32}$ National Armed Forces Law, www.vvc.gov.lv/ National_Armed_Forces_Law.doc
} 
tais nèra tobula, nes ji nebuvo pataisyta. ${ }^{33}$

Turint galvoje globalių saugumo ir gynybos grèsmių, pavojų ir iššūkių pobūdị ir XXI amžiuje iš esmès pasikeitusị karinių konfliktų pobūdị, reikia spręsti naujus iššūkius, su kuriais ir susiduria Latvijos Respublikos prezidentas, parlamentas ir vyriausybe், siekdami sèkmingai atlikti savo pareigas valstybès gynybos srityje, remdamiesi Latvijos Respublikos Konstitucija. Atsižvelgiant i tai, kad prezidentas, parlamentas ir vyriausybè turi igaliojimus imtis labai svarbių ir neatidèliotinų veiksmų, tokių kaip sprendimas dẻl karo pradžios, karo paskelbimas, vyriausiojo kariuomenès vado skyrimas, nepaprastosios padèties paskelbimas Latvijos Respublikos teritorijoje, savo teisinès kompetencijos ribose, akivaizdu, kad pagrindinis bet kurio priešininko uždavinys bus sužlugdyti ir panaikinti galimybę rinktis, tartis, priimti sprendimus ir skelbti reikalingus įsakymus ir dokumentus. Dèl šių priežasčių jie tampa labai parankūs taikiniai priešininkui planuojant veiksmus, skirtus sužlugdyti ir nutraukti laiku atliekamas ir profesionalias sprendimų prièmimo procedūras ir susitarimus dèl karinio vadovavimo ir kontrolès.

Reikia pripažinti, kad Latvijos Respublikos teisinè ir institucinè struktūra, susijusi su valstybès saugumo ir gynybos klausimais, yra tinkamai parengta, tačiau, siekdamos efektyviai atlikti savo pareigas, saugumo ir gynybos institucijos susiduria su rimtais sunkumais, kylančiais dèl įvairių priežasčių, kurios bus išdèstytos kitame skyriuje.

\section{Būsimi Latvijos saugumo ir gynybos politikos iššūkiai}

Siekdamos Latvijos saugumo ir gynybos politikos efektyvumo, jos institucijos susiduria ir artimiausioje ateityje susidurs su rimtais iššūkiais, kuriuos lemia įvairios vidaus ir išorès priežastys. Egzistuoja kelios esminès išorinès priežastys, kurios gali stipriai paveikti Latvijos saugumo ir gynybos politiką. Pirmiausia, Jungtinių Amerikos Valstijų poslinkio į Ramiojo vandenyno regiono valstybes strategija ir sumažèjęs Amerikos karinis buvimas Europoje paveiks ir vieno iš svarbiausių Latvijos saugumo ir gynybos politikos ramsčių efektyvumą. Nors NATO oro policijos misija Baltijos valstybėse buvo pratęsta,

\footnotetext{
${ }^{33}$ Oškalne S., "Supreme Command and Control of the Armed Forces: the Roles of Presidents, Parliaments, Governments, Ministries of Defence and Chiefs of Defence" in Lawrence T.\& Jermalavičius T., eds., Apprenticeship, Partnership, Membership: Twenty Years of Defence Development in the Baltic States, Tallinn: International Centre for Defence Studies, 2013, p. 136.
} 
NATO nenumatytų atvejų planai Baltijos regionui patvirtinti, o vèliau, $2013 \mathrm{~m}$. lapkričio mèn., i̇vyko NATO Greitojo reagavimo pajėgų pratybos „Steadfast Jazz 2013“, minètų NATO pratybų tikslas ir mastas atkreipé dèmesị ị keletą vidinių ir išorinių dalykų. Pagrindinis karinių pratybų „Steadfast Jazz 2013“ tikslas buvo patikrinti tiek kovini pratybose dalyvaujančių pajègų, tiek ịvairių NATO štabų kadrų, vadovaujančių NATO NRF kariams ir juos kontroliuojančių, pasirengimą. Žinoma, minètos pratybos buvo numatytos iš anksto, taigi dèl šios priežasties ir Rusijos Federacija, ir NATO vykdè didelio masto karines pratybas labai arti vieni kitų, o ir planuoto laiko atžvilgiu jos buvo labai artimos. Galima būtų teigti, kad „Steadfast Jazz 2013“ pratybos buvo didžia dalimi politiškai sąlygotas renginys, siekiant perduoti kai kuriuos politinius ir diplomatinius signalus. Pirmiausia, tai buvo vidaus žinia NATO šalims, kad NFR pajègos veikia ir, esant reikalui, gali būti panaudotos; antra, tai buvo žinia Baltijos valstybėms, siekiant užtikrinti jas, kad NATO ịsipareigojimai galioja visiems Aljanso nariams; ir trečia, tai buvo tam tikras politinis atsakas ị prieš tai vykusias Rusijos Federacijos karines pratybas „Zapad 2013“. Vis delto, galima teigti, kad buvo keletas požymių, kad Jungtinių Amerikos valstijų strateginis poslinkis Ramiojo vandenyno regiono link turès tiesioginès įtakos Europos valstybėms - NATO narėms, o ypač Aljanso narèms - Baltijos valstybėms. Pirma, Jungtinès Amerikos Valstijos - šalis, kuri daugiausiai skiria NATO lešs̨ ir karinių pajègumų atžvilgiu - dalyvavo šiose pratybose kukliai, atsiųsdami vos kelis šimtus karių, o „Steadfast Jazz 2013“ pratybose iš viso dalyvavo maždaug 6000 karių. Antra, bendras pratybose dalyvavusių karių skaičius buvo žymiai mažesnis negu Rusijos ir Baltarusijos karių, dalyvavusių „Zapad 2013“ karinèse pratybose. Galima būtų tvirtinti, kad aukščiau pateikti faktai yra Jungtinių Amerikos Valstijų signalas Rusijos Federacijai, kuris rodo, kad situacija globalaus ir regioninio saugumo kontekste reikalauja, kad Amerikos kariniai pajègumai būtų dislokuoti daug svarbesniuose regionuose, taip pat leidžia aiškiai suprasti, kad Europos ir Baltijos regiono amerikiečiai nelaiko potencialiai pavojingu saugumo ir gynybos požiūriu. Be to, būtų galima daryti išvadą, kad Europa ir Baltijos valstybès ir Jungtinių Amerikos Valstijų, ir Rusijos Federacijos saugumo darbotvarkès prioritetų sąraše išlieka palyginti nesvarbios. Vis dèlto, žiūrint iš NATO perspektyvos, reikejjo pasiųsti politinị signalą Latvijos ir kitų Baltijos valstybių vadovams, siekiant užtikrinti juos dèl Aljanso ịsipareigojimų Baltijos valstybėms. NATO Generalinio sekretoriaus Anderso Fogho Rasmusseno vizitas $\mathfrak{i}$ Latviją pratybų metu ir jo susitikimas su trijų Baltijos valstybių prezidentais buvo politinė NATO vadovų žinia Baltijos valstybėms.

Kitas labai svarbus klausimas yra vis didẻjantis karinių išlaidų skirtumas tarp Jungtinių Amerikos Valstijų ir Europos valstybių (NATO narių), kuris turès neigiamą poveikị NATO sugebejjimui išlikti veiksminga karine sąjunga. 
Būsimas NATO viršūnių susitikimas Kardifo mieste (Valija) bus nepaprastai svarbus Latvijos Respublikos saugumo ir gynybos ateičiai. Pirma, dabartinis NATO Generalinis sekretorius Rasmussenas pasitrauks iš posto, todel valstybès (Aljanso narès) turi nuspręsti, kas bus kitas Generalinis sekretorius. Aljanso vadovo asmenybe mažosioms valstybèms, taip pat ir Latvijai, yra daug svarbesnè negu politiniu ir kariniu požiūriu galingoms NATO narèms. Antra, apskritai, NATO padètis yra bloga dèl to, kad keletas svarbiausių Aljanso valstybių užsiima ịvairių neatidèliotinų problemų sprendimu, tokiu būdu palikdamos gynybos reikalus nuošalèje. Jungtinès Amerikos Valstijos su savo posūkiu Ramiojo vandenyno regioną laiko NATO vis mažiau reikšminga Amerikos saugumui dèl nuolatinio NATO narių Europoje nesugebejimo vykdyti savo ìsipareigojimų gynybos srityje. Panašu, kad Jungtinę Karalystę labiau domina 2015 metų visuotiniai rinkimai, o ne artimiausia Aljanso ateitis. Prancūzija nusprende įsikišti ị Malio ir Centrinès Afrikos Respublikos reikalus be NATO karinès paramos. Vokietija turi savų sunkumų vidaus ir užsienio politikoje. Be to, karinėms priemonèms nepritariančios Europos bendruomenès ir toliau mažins Europos galimybę būti svarbiu veikejju kietojo saugumo srityje. ${ }^{34}$ Tai reiškia, kad du pagrindiniai Latvijos saugumo ir gynybos ramsčiai - Amerikos ịsipareigojimas besąlygiškai ginti Latviją ir vis daugiau problemų keliantys klausimai, susiję pačios Europos įsipareigojimais Europos gynybos srityje žymiai padidinti Europos karinị biudžetą ir Europos karinius pajegumus, - patirs rimtų išbandymų. Taigi, žiūrint iš Latvijos perspektyvos, pagrindinių Aljanso veikejjų požiūris neabejotinai rodo, kad šiuo metu NATO trūksta darnos, o tai yra nerimą keliantis signalas Latvijai. Galima daryti išvadą, kad sprendimai, kurie bus priimti būsimajame NATO viršūnių susitikime, bus labai svarbūs Latvijos Respublikai.

Labai reikšmingi vidaus aspektai, turèsiantys ịtakos tolesniam Latvijos saugumo ir gynybos politikos plettojimui, yra šie: politinis ir ekonominis pasižadejimas laikytis ịsipareigojimų iki 2020 metų žymiai padidinti Latvijos gynybos išlaidas iki $2 \%$ nuo BVP. ${ }^{35}$ Latvija planavo pasiekti $2 \%$ iki 2013 metų, tačiau dèl sunkių ekonominès krizès pasekmių ji vis dar labai atsilieka. ${ }^{36}$ Demografinès problemos sukels didelių sunkumų, pritraukiant ir išlaikant kvalifikuotus kadrus. ${ }^{37}$ Politinès valios stoka, ekonominiai sunkumai, siekiant toliau didinti išlaidas Latvijos gynybai, tolesni demografiniai sunkumai sukels didelių

\footnotetext{
${ }^{34}$ Grey C.S., (4 išnaša). P. 117.

${ }^{35}$ Kaljurand R., Neretnieks K., Ljung B., Tupay J., (8 išnaša). P. 40.

${ }^{36}$ Molder H., "The Development of Military Cultures" in Lawrence T.\& Jermalavičius T., eds., Apprenticeship, Partnership, Membership: Twenty Years of Defence Development in the Baltic States, Tallinn: International Centre for Defence Studies, 2013, p. 110.

${ }^{37}$ Kaljurand R., Neretnieks K., Ljung B., Tupay J., (8 išnaša). P. 41.
} 
problemų, pritraukiant ir išlaikant kvalifikuotus ir igudusius kadrus, sumažins galimybę plètoti Latvijos nacionalines gynybos pajègas, ịsigyti naujų karinių pajègumų ir, pagaliau, iškils esminis klausimas dèl Latvijos sugebejjimo išlaikyti klasikinę sausumos, oro, jūrų, specialiųjų operacijų, logistinès paramos, mokymo ir doktrinų subjektų karinę struktūrą iki 2020 metų. Artimiausioje ateityje Latvijos saugumo ir gynybos politikai iškils esminè dilema: ar ir toliau palaikyti klasikinę karinių pajègų struktūrą, kurią sudaro sausumos pajėgos, karinis jūrų laivynas, oro pajègos, specialiųjų operacijų pajègos, logistinè parama ir mokymo ir doktrinų padaliniai, ar pertvarkyti Latvijos Respublikos ginkluotąsias pajegas ị siauros specializacijos karines pajègas, kurios turès didelę pridedamąją vertę būsimoms NATO operacijoms. Atrodo, kad pirmąji variantą ateityje bus labai sunku išlaikyti ir palaikyti. Galima būtų teigti, kad nepaisant politinio įsipareigojimo 2020 metais padidinti Latvijos gynybos išlaidas iki $2 \%$ nuo BVP, nèra patikimų požymių, kad šios išlaidos bus žymiai padidintos 2014 ir 2015 metais, todèl akivaizdu, kad dabartinè Latvijos Respublikos ginkluotųjų pajègų struktūra negalès turèti ir panaudoti šiuolaikinių kovinių pajegumų. Galima daryti išvadą, kad svarbūs išoriniai ir vidiniai aspektai kelia didelius iššǔkius dabartinei Latvijos saugumo ir gynybos politikai, o kartu ir instituciniam valstybès saugumo ir gynybos sektoriaus veiksmingumui.

\section{Išvados}

XXI amžiaus pradžioje globaliam, regioniniam ir nacionaliniam saugumui iškilo nauji pavojai ir iššūkiai. Būdama visateisè NATO ir ES narè, Latvija yra saugi kaip niekada per visą savo istoriją. Tačiau kadangi Latvijos Respublikos valstybės siena su Rusija yra ir NATO ir ES siena su Rusija, dvišaliai santykiai tarp Jungtinių Amerikos Valstijų ir Rusijos, taip pat NATO ir Rusijos santykiai, turi didelę ịtaką Latvijos Respublikos ir kitų Baltijos valstybių saugumo ir gynybos politikai.

Galima sakyti, kad svarbiausi veiksniai, kurie lemia Latvijos saugumo ir gynybos aplinkybes ir politiką, kyla iš šiu ypatybių: geografinès padeties, istorinių aplinkybių, artimos kaimynystès su Rusija, palyginti mažo šalies dydžio, šalies etninès gyventojų sudèties ir pasitikejjimo Jungtinėmis Amerikos Valstijomis ir NATO kaip pagrindiniais saugumo ir gynybos garantais. Dél šios priežasties pagrindiniai Latvijos saugumo ir gynybos politikos principai yra koncentruoti i pastangas, siekiant sumažinti karinès grèsmès galimybę Latvijai, stiprinant kolektyvinị saugumą ir kolektyvinę gynybą, plètojant strateginę partnerystę su Jungtinèmis Amerikos Valstijomis, dalyvaujant NATO ir ES, vystant Šiaurès ir Baltijos šalių bendradarbiavimą saugumo ir gynybos srityje. 
Visgi, būtų galima teigti, kad pragmatiški ir draugiški santykiai su Rusija galètų stipriai lemti vieną iš pagrindinių Latvijos saugumo ir gynybos ramsčių, t. $y$. sumažinti karinę grèsmę Latvijos Respublikai.

Dabartiniu metu ir artimoje ateityje vidiniai ir išoriniai Latvijos saugumo ir gynybos politikos ramsčiai patirs didelių išbandymų dèl vykstančių fundamentalių pokyčių globalioje, regioninèje ir nacionaliniame saugumo ir gynybos kontekste. Pirmiausia, Jungtinès Amerikos Valstijos dèl savo Ramiojo vandenyno regiono strategijos ir globalaus saugumo problemų kituose regionuose žymiai sumažins karinius ịsipareigojimus Europai. Antra, akivaizdu, kad dèl didelio ir nesuderinto gynybos išlaidų mažinimo NATO šalyse Europoje, Europa vis dar nèra pasiruošusi prisiimti pagrindinės atsakomybès už savo saugumą ir gynybą. Todèl tai gali pakenkti NATO sugebejjimui išlikti veiksminga organizacija. Egzistuoja keletas pagrindinių vidaus problemų, kurios ir toliau gali neigiamai veikti Latvijos saugumo ir gynybos politiką: politinès valios stoka didinti gynybos išlaidas iki planuojamų $2 \%$ nuo BVP, išliekantys ekonominiai sunkumai, demografinès problemos. Suprantama, kad visi šie klausimai turès įtakos instituciniam Latvijos saugumo ir gynybos sektoriaus plettojimui.

Be abejo, tolesnis Latvijos Respublikos ir kitų Baltijos valstybių saugumo ir gynybos politikos formavimas priklausys nuo NATO sugebejjimo išlikti veiksminga organizacija, pasižyminčia veiksmingu sprendimų prièmimo procesu laiku, taip pat nuo Jungtinių Amerikos Valstijų sugebejjimo ir toliau būti kariniu požiūriu veiksmingomis ir laikytis įsipareigojimų Europos saugumui ir gynybai. Vertetų pridurti, kad šios politikos formavimas taip pat priklausys nuo dvišalių santykių tarp Latvijos ir Rusijos, Jungtinių Amerikos Valstijų ir Rusijos ir NATO ir Rusijos. Rusijos Federacija yra svarbus veikèjas Baltijos regione, todèl Latvijos Respublika yra labai suinteresuota palaikyti pragmatiškus ir racionalius santykius su Rusija. Vargu, ar galima būtų teigti, kad Baltijos valstybių karinis bendradarbiavimas taktiniu lygmeniu turètų būti stiprinamas, tačiau operaciniu ir strateginiu lygmeniu visos trys šalys susiduria su labai panašiomis saugumo problemomis ir susitarimais NATO rėmuose, taip pat santykiuose su Jungtinèmis Amerikos Valstijomis. Reiktų stiprinti ir Šiaurès ir Baltijos šalių karinị bendradarbiavimą, tačiau jis negali pakeisti NATO saugumo garantijų ar Jungtinių Amerikos Valstijų dalyvavimo Europos ir Baltijos regiono gynyboje. 